\title{
Effects of Plant Residue Additives and Soil Moisture on Growth and Mn Content of Soybean Seedlings ${ }^{1}$
}

\author{
A. Vélez-Ramos and L. Standifer ${ }^{2}$
}

\begin{abstract}
Greenhouse experiments were conducted to study the effects of decomposing alfalfa meal additives and soil moisture on the Mn content of soybean seedlings (Glycine max L.). Soybean seedlings were grown in soil to which alfalfa meal was added in quantities from 0 to $4 \%$. After the seedlings were established, the soil was subjected to flooding or near field capacity moisture for 7 days. In the absence of alfalfa meal, seedling growth was similar at both soil moisture levels. Increased levels of alfalfa meal progressively reduced germination and growth rate of seedlings. These effects were more pronounced in the flooded soil. Flooding resulted in a marked increase of seedling Mn content, whereas increasing alfalfa meal caused no definite change.
\end{abstract}

\section{INTRODUCTION}

For several years the Horticulture Department of Louisiana State University has been studying a system of multiple cropping under conditions where wet soil may cause substantial delays in seedbed preparation. This system employs the concept of minimum tillage in which all weeds are controlled with herbicides and raised seedbeds are used to provide drainage. After harvest, plant residues are cut to ground level and the next crop is immediately planted through the stubble. If this system could be commercially implemented, it would allow much more efficient use of productive land in tropical and subtropical areas.

Although the program has been generally successful, a problem of Mn toxicity sometimes occurs when southern peas (Vigna sinensis L.) are planted in the decaying stubble of sweet corn (Zea mays L.). Because the soil had been subjected to almost daily rain during the week that the pea seedlings were emerging from the soil, it was postulated that the problem involved temporary reduction of Mn caused by rapid decomposition of corn roots in wet soil.

$\mathrm{Mn}$ is generally considered to be one of the more important toxic metals in acid soils (10). The occurrence of Mn toxicity in plants has been well established, mainly from experiments using non-soil cultures $(7,12)$.

${ }^{1}$ Manuscript submitted to Editorial Board June 7, 1976. Part of a thesis submitted to the faculty of the Graduate School of Louisiana State University in partial fulfillment of the requirements for the Ph.D. degree.

${ }^{2}$ Associate Agronomist, Agricultural Experiment Station, University of Puerto Rico; Professor, Department of Horticulture, Louisiana State University, Baton Rouge, La. 
Manganic oxides undergo reduction in anaerobic soils, forming the more soluble manganous compounds (11). In terms of redox potentials (Eh), Turner and Patrick (14) reported that Mn began to be reduced at an Eh of $+400 \mathrm{mV}$ and was essentially completely reduced at an Eh of $+200 \mathrm{mV}$.

Several investigators $(2,4,5)$ reported that the reduction of $\mathrm{Mn}$ was favored by the presence of readily decomposable organic matter. Reduction of the higher Mn oxides in waterlogged soils takes place when the biological oxidation of organic matter proceeds so rapidiy that air cannot supply $\mathrm{O}_{2}$ in adequate amounts.

The primary objectives of the work reported here were: a) to study the influence of added plant residues and soil moisture on the Mn content and growth of soybean seedlings; and b) to determine its possible relationship to the observed Mn toxicity in southern peas in a multiple cropping system.

\section{MATERIALS AND METHODS}

One experiment for each of four soils (Olivier, Sharkey, Commerce, and Convent) was established in the greenhouse and data were collected separately for the 1974 and 1975 experiments. Soil physical and chemical properties are presented in table 1. Each experiment consisted of eight treatments and four replications in a complete randomized block design.

Alfalfa meal prepared as poultry feed was mixed thoroughly with 250 $\mathrm{g}$ of soil at rates ranging from 0 to $2 \%$ (except for the germination study shown in table 2 , in which a $4 \%$ treatment was included) and placed in plastic pots $11 \mathrm{~cm}$ in diameter and $5 \mathrm{~cm}$ deep. Ten soybean seeds were planted in each pot and water was added so that during the germination period water made up $15 \%$ of the weight of each pot. After germination each pot was thinned to 5 seedlings and water added so that water made up $25 \%$ of the weight of half of the pots; the other half were brought to a waterlogged state. These moisture levels were kept constant during the incubation period by periodical addition of water, using the weightdifference method.

The seedlings were allowed to grow for 7 days; at the end of this time the above-ground portion of each plant was harvested and the fresh weight recorded. The plant material was dried in a forced-air oven at $70^{\circ}$ $\mathrm{C}$ for $24 \mathrm{~h}$ and ground in a Wiley mill to pass a 20 -mesh screen. A 1 -g sample was weighed into a Gooch crucible and ashed in a muffle furnance for $4 \mathrm{~h}$ at $550^{\circ} \mathrm{C}$. The ash was dissolved in $10 \mathrm{ml}$ of $50 \% \mathrm{HCl}$ and the solution heated on a hot plate until it cleared up and then filtered through Whatman \#2 filter paper. The filter paper was washed with hot water several times and the volume brought to $100 \mathrm{ml}$ with distilled 
TABLE 1.-Physical and chemical characteristics of the soils used

\begin{tabular}{|c|c|c|c|c|}
\hline \multirow{2}{*}{ Soil Property } & \multicolumn{4}{|c|}{ Soil series } \\
\hline & Olivier & Sharkey & Commerce & Convent \\
\hline Parent material & Loess & $\begin{array}{l}\text { Montmorillonitic } \\
\text { clayey Missis- } \\
\text { sippi river al- } \\
\text { luvial deposits }\end{array}$ & $\begin{array}{l}\text { Mississippi river } \\
\text { deposits, silt, } \\
\text { clays }\end{array}$ & $\begin{array}{lr}\text { Recent alkaline } \\
\text { alluvium de- } \\
\text { posited by } \\
\text { river spill- } \\
\text { overs and } \\
\text { levee break- } \\
\text { downs }\end{array}$ \\
\hline Texture & Silt loam & Clay & Silt Ioam & Sandy loam \\
\hline $\begin{array}{l}\mathrm{pH}(1: 1 \text { soil wa- } \\
\text { ter) }\end{array}$ & 6.4 & 6.8 & 7.3 & 7.5 \\
\hline $\begin{array}{l}\text { Organic matter } \\
\text { (O.M.) (\%) }\end{array}$ & .88 & 2.44 & 1.82 & .31 \\
\hline $\begin{array}{l}\text { Extractable } \\
(\mathrm{p} / \mathrm{m})\end{array}$ & 10 & 18 & 13 & 8 \\
\hline $\begin{array}{l}\text { Extractable } P(p / \\
m)\end{array}$ & 123 & 256 & 261 & 209 \\
\hline $\begin{array}{l}\text { Extractable K (p/ } \\
\text { m) }\end{array}$ & 157 & 268 & 196 & 122 \\
\hline $\begin{array}{l}\text { Extractable } \\
(\mathrm{p} / \mathrm{m})\end{array}$ & 770 & $4000+$ & 3160 & 1090 \\
\hline $\begin{array}{l}\text { Extractable } \\
(\mathrm{p} / \mathrm{m})\end{array}$ & 78 & $1000+$ & 711 & 363 \\
\hline
\end{tabular}

water, resulting in a 1:100 sample dilution. From this dilution, Mn content was determined in the atomic absorption spectrophotometer.

\section{RESULTS AND DISCUSSION}

The effect of decomposing alfalfa meal on the germination of soybean seedlings grown in four different soil types is summarized in table 2 . The percent germination in the control treatment ranged from 74 to $100 \%$ throughout the incubation period, while that of $4 \%$ alfalfa meal ranged from 5 to $63 \%$. The percent germination was markedly reduced by added alfalfa meal, with no less than $2 \%$ for the Olivier and $4 \%$ for the other three soils.

The precise mechanism whereby decomposing alfalfa meal residues affected seed germination is not clearly understood. One possibility is an increased demand for $\mathrm{O}_{2}$ in the oxidation of soil organic matter and in microbial respiration due to increased concentration of decomposing plant residues. This curtailed supply of $\mathrm{O}_{2}$ to the germinating seed and the emerging seedling may lead to a reduction or complete termination of respiration during the germination process. If large amounts of plant residues are added to the soil, i.e., $4 \%$, rapid depletion of soil $\mathrm{O}_{2}$ may be 
TABLE 2,-Percent germination of soybean seedlings grown in four soil types with variable organic matter additive treatments

\begin{tabular}{|c|c|c|c|c|c|c|c|c|c|c|c|c|}
\hline \multirow{4}{*}{ Treatment } & \multicolumn{12}{|c|}{ Percent germination } \\
\hline & \multicolumn{12}{|c|}{ Time of incubation (days) } \\
\hline & 3 & 5 & 7 & 3 & 5 & 7 & 3 & 5 & 7 & 3 & 5 & 7 \\
\hline & \multicolumn{3}{|c|}{ Olivier } & \multicolumn{3}{|c|}{ Sharkè } & \multicolumn{3}{|c|}{ Commerce } & \multicolumn{3}{|c|}{ Convent } \\
\hline Control & 68 & 88 & 88 & 100 & 100 & 100 & 74 & 77 & 83 & 83 & 83 & 83 \\
\hline $0.5 \%$ Alfalfa meal & 61 & 72 & 83 & 68 & 72 & 88 & 57 & 74 & 85 & 85 & 91 & 91 \\
\hline $1.0 \%$ Alfalfa meal & 44 & 72 & 83 & 83 & 85 & 85 & 50 & 68 & 74 & 88 & 91 & 88 \\
\hline $2.0 \%$ Alfalfa meal & 16 & 41 & 44 & 63 & 80 & 88 & 30 & 50 & 72 & 41 & 74 & 74 \\
\hline $4.0 \%$ Alfalfa meal & 5 & 11 & 30 & 44 & 63 & 63 & 38 & 50 & 52 & 18 & 50 & 41 \\
\hline \multirow{2}{*}{$\begin{array}{l}\text { L.S.D. for incubation } \\
\text { time }\end{array}$} & .05 & \multirow{2}{*}{\multicolumn{2}{|c|}{$\begin{array}{l}8.4 \\
6.3\end{array}$}} & \multirow{2}{*}{\multicolumn{3}{|c|}{$\begin{array}{r}13.6 \\
9.3\end{array}$}} & \multirow{2}{*}{\multicolumn{3}{|c|}{$\begin{array}{r}11.0 \\
8.3\end{array}$}} & \multirow{2}{*}{\multicolumn{3}{|c|}{$\begin{array}{l}8.5 \\
6.4\end{array}$}} \\
\hline & .05 & & & & & & & & & & & \\
\hline \multirow{2}{*}{$\begin{array}{l}\text { L.S.D. for alfalfa meal } \\
(\%)\end{array}$} & .01 & \multirow{2}{*}{\multicolumn{2}{|c|}{$\begin{array}{r}10.8 \\
8.2\end{array}$}} & \multirow{2}{*}{\multicolumn{3}{|c|}{$\begin{array}{l}16.1 \\
12.2\end{array}$}} & \multirow{2}{*}{\multicolumn{3}{|c|}{$\begin{array}{l}14.2 \\
10.8\end{array}$}} & \multicolumn{3}{|c|}{11.0} \\
\hline & .01 & & & & & & & & & & 8.3 & \\
\hline
\end{tabular}

Percent germination 
TABLE 3.-Fresh weight of soybean seedlings grown in four soil types with variable moisture and organic matter additive treatments

\begin{tabular}{|c|c|c|c|c|c|c|c|c|c|}
\hline \multicolumn{2}{|c|}{ Treatment } & \multicolumn{8}{|c|}{ Fresh weight (g/seedling) } \\
\hline \multirow{2}{*}{ Alfalfa meal } & \multirow{2}{*}{ Moisture } & \multicolumn{2}{|c|}{ Olivier } & \multicolumn{2}{|c|}{ Sharkey } & \multicolumn{2}{|c|}{ Commerce } & \multicolumn{2}{|c|}{ Convent } \\
\hline & & 1974 & 1975 & 1974 & 1975 & 1974 & 1975 & 1974 & 1975 \\
\hline$\%$ & $\%$ & & & & & & & & \\
\hline 0 & 25 & 1.17 & 1.39 & 1.28 & 1.23 & 0.97 & 1.03 & 0.87 & 0.86 \\
\hline .5 & 25 & 1.08 & 1.26 & 1.10 & .96 & 1.07 & 1.06 & .94 & .91 \\
\hline 1.0 & 25 & 1.04 & 1.18 & 1.03 & .92 & 1.08 & 1.10 & .77 & .83 \\
\hline 2.0 & 25 & .86 & 1.19 & .97 & .93 & 1.16 & 1.09 & .76 & .82 \\
\hline 0 & 60 & 1.16 & 1.10 & 1.08 & 1.27 & 1.29 & 1.24 & 1.14 & 1.28 \\
\hline .5 & 60 & 1.15 & 1.12 & 1.12 & 1.07 & .96 & 1.22 & 1.25 & 1.38 \\
\hline 1.0 & 60 & 1.02 & .95 & .78 & 1.02 & 1.04 & .95 & 1.31 & 1.41 \\
\hline 2.0 & 60 & .68 & .82 & .74 & .84 & .73 & .77 & 1.18 & 1.02 \\
\hline L.S.D. & $\begin{array}{l}\text { Moisture (\%) } \\
\text { Alfalfa meal }(\%)\end{array}$ & $\begin{array}{l}\text { N.S. } \\
.12^{* *}\end{array}$ & $\begin{array}{l}.17^{* * 1} \\
.18^{*}\end{array}$ & $\begin{array}{l}.14^{* 2} \\
.26^{* *}\end{array}$ & $\begin{array}{l}\text { N.S. } \\
.19 * *\end{array}$ & $\begin{array}{l}\text { N.S. } \\
\text { N.S. }\end{array}$ & $\begin{array}{l}\text { N.S. } \\
.17^{* *}\end{array}$ & $\begin{array}{l}.15^{* *} \\
\text { N.S. }\end{array}$ & $\begin{array}{l}.17 * * \\
\text { N.S. }\end{array}$ \\
\hline
\end{tabular}

$1 * *$ L.S.D. at .01 level of probability.

$2 *$ L.S.D. at .05 level of probability. 
expected immediately following its addition. This $\mathrm{O}_{2}$ depletion is more likely to occur in localized areas around the germinating seed where the $\mathrm{O}_{2}$ demand is very high as compared to the surrounding soil.

Another manner in which decomposing plant residues may affect seed germination is by the formation of toxic substances. In this connection Toussoun et al. (13) reported that some phytotoxic effects noted from substances produced during decomposition of organic matter were an inhibition or delay of seed germination, seed killing, necrosis of roots, and inhibition of growth and root hair development of tobacco, lettuce, and bean seedlings. McCalla and Haskin (6), Patrick and Koch (8), and Patrick and Toussoun (9) noted that the decomposition of plant organic matter is often accompanied by formation of substances with phytotoxic properties. Among the reported toxic substances are: benzoic, phenylacetic, 3-phenylpropionic, and phenylbutyric acids (13); chlorogenic acid, P-coumaric acid, and P-hydroxybenzaldehyde (1); and the bacterial growth inhibitors gallic, gallotanic, and chlorogenic acids (3). The present investigation did not provide for identification of such substances or any other organic substance produced during incubation.

The fresh weight of seedlings (table 3 ) was generally reduced by flooding and also by increasing the concentration of alfalfa meal in the soil although exceptions were observed. Thus, increasing alfalfa meal concentration produced no significant reduction in the fresh weight of newly emergent seedlings in Convent or Commerce soils for the 1974 samples, while flooding caused an increase in fresh weight of seedlings grown in Convent soil. The depressing effect of applied alfalfa meal on the fresh weight was more pronounced under flooded conditions.

Table 4 summarizes the effects of alfalfa meal and soil moisture on the $\mathrm{Mn}$ content of soybean seedlings. Flooding increased the Mn content of seedlings in all soils under study. In general, Mn content was highest in

TABLE 4. - Mn concentration of soybean seedlings grown in four soil types with variable moisture and organic matter additive treatments

\begin{tabular}{|c|c|c|c|c|c|c|c|c|c|}
\hline \multicolumn{2}{|c|}{ Treatment } & \multicolumn{8}{|c|}{ Mn concentration $(\mathrm{p} / \mathrm{m})$} \\
\hline \multirow{2}{*}{$\begin{array}{c}\text { Alfalfa } \\
\text { meal }\end{array}$} & \multirow{2}{*}{$\begin{array}{l}\text { Mois- } \\
\text { ture }\end{array}$} & \multicolumn{2}{|c|}{ Olivier } & \multicolumn{2}{|c|}{ Sharkey } & \multicolumn{2}{|c|}{ Commerce } & \multicolumn{2}{|c|}{ Convent } \\
\hline & & 1974 & 1975 & 1974 & 1975 & 1974 & 1975 & 1974 & 1975 \\
\hline$\%$ & $\%$ & & & & & & & & \\
\hline 0 & 25 & 190 & 109 & 59 & 66 & 57 & 47 & 54 & 44 \\
\hline .5 & 25 & 140 & 100 & 5.5 & 69 & 49 & 49 & 47 & 50 \\
\hline 1.0 & 25 & 70 & 93 & 48 & 67 & 50 & 51 & 43 & 54 \\
\hline 2.0 & 25 & 80 & 131 & 49 & 79 & 55 & 47 & 41 & 47 \\
\hline 0 & 60 & 380 & 395 & 102 & 76 & 108 & 73 & 76 & 72 \\
\hline .5 & 60 & 300 & 288 & 116 & 79 & 144 & 84 & 66 & 76 \\
\hline 1.0 & 60 & 390 & 231 & 131 & 103 & 136 & 89 & 68 & 85 \\
\hline 2.0 & 60 & 490 & 266 & 122 & 86 & 202 & 137 & 83 & 100 \\
\hline
\end{tabular}


TABLE 5.-Ammonium acetate-soluble Mn of four soil types given variable moisture and organic matter additive treatments in the greenhouse study. Sampled in 1974 and 1975

\begin{tabular}{|c|c|c|c|c|c|c|c|c|c|c|}
\hline \multicolumn{2}{|c|}{ Treatment } & \multicolumn{9}{|c|}{ Extractable $\mathrm{Mn}(\mathrm{p} / \mathrm{m})$} \\
\hline \multirow{2}{*}{ Alfalfa meal } & \multirow{2}{*}{ Moisture } & \multicolumn{2}{|c|}{ Olivier } & \multicolumn{2}{|c|}{ Sharkey } & \multicolumn{2}{|c|}{ Commerce } & \multicolumn{3}{|c|}{ Convent } \\
\hline & & 1974 & 1975 & 1974 & 1975 & 1974 & 1975 & 1974 & & 1975 \\
\hline$\%$ & $\%$ & & & & & & & & & \\
\hline 0 & 25 & 13 & 6 & 6 & 9 & 4 & 8 & 6 & 4 & \\
\hline .5 & 25 & 14 & 6 & 5 & 17 & 5 & 11 & 7 & 4 & \\
\hline 1.0 & 25 & 20 & 7 & 7 & 23 & 7 & 17 & 9 & 7 & \\
\hline 2.0 & 25 & 34 & 5 & 10 & 32 & 13 & 38 & 11 & 10 & \\
\hline 0 & 60 & 581 & 465 & 125 & 270 & 177 & 133 & 105 & 100 & \\
\hline .5 & 60 & 691 & 516 & 139 & 299 & 219 & 221 & 104 & 89 & \\
\hline 1.0 & 60 & 780 & 647 & 153 & 292 & 234 & 259 & 98 & 97 & \\
\hline 2.0 & 60 & 729 & 539 & 145 & 284 & 221 & 240 & 91 & 89 & \\
\hline \multirow[t]{2}{*}{ L.S.D. } & Moisture (\%) & $34.6^{* * 1}$ & $79.8^{* *}$ & $12.6^{* *}$ & $12.8 * *$ & $10.0^{* *}$ & $17.4 * *$ & $13.7 *$ & & $10.4^{* *}$ \\
\hline & Alfalfa meal (\%) & $48.9 * *$ & N.S. ${ }^{2}$ & N.S. & $18.2^{* * *}$ & $13.0^{* *}$ & $24.6^{* *}$ & N.S. & & N.S. \\
\hline
\end{tabular}

$1 * *$ L.S.D. at .01 level of probability.

2 Not significant. 
seedlings grown in Olivier soil, intermediate for those grown in Sharkey and Commerce, and lowest in seedlings grown in Convent soil. This sequence of soils according to the Mn content of seedlings corresponds to a similar sequence of increasing soil pH (table 1) indicating an inverse relationship between soil $\mathrm{pH}$ and the $\mathrm{Mn}$ content of seedlings.

The effect of alfalfa meal concentration on Mn uptake by soybean seedlings appears to be extremely variable and no clear-cut trend emerges. But it seems that at the high moisture level (60\%), high concentrations of alfalfa meal in soil were associated with high $\mathrm{Mn}$ content of seedlings, except for Olivier soil. Large variations in Mn content of seedlings among sampling dates were evident. This lack of uniformity may be a consequence of the observed detrimental effect from applied alfalfa meal on the germination and growth of seedlings.

The data on Mn uptake by soybean seedlings failed to show a significant effect of decomposing plant residues on the concentration of $\mathrm{Mn}$ in plant tissue. The data also failed to implicate $\mathrm{Mn}$ as a possible cause of the observed depression of seedling germination and growth.

Since Mn content of soybean seedlings was generally low, except for those grown in flooded Olivier soil, and there was no evidence of $\mathrm{Mn}$ toxicity symptoms in the developing seedlings, it may be assumed that some other factor or factors were responsible for the reduction in growth of soybean seedings. From the data obtained, no significant effects can be ascribed to the decaying stubble of sweet corn on the observed $\mathrm{Mn}$ toxicity of southern peas in the multiple cropping system mentioned in the introduction.

As indicated in table 5, increasing the soil moisture from 25 to $60 \%$ produced a highly significant increase in the $\mathrm{NH}_{4} \mathrm{Ac}$-extractable $\mathrm{Mn}$ content for all four soils under study. These increases ranged from 568 $\mathrm{p} / \mathrm{m}$ for Olivier to $99 \mathrm{p} / \mathrm{m}$ for Convent in the 1974 samples, and from 459 $\mathrm{p} / \mathrm{m}$ to $96 \mathrm{p} / \mathrm{m} \mathrm{Mn}$, respectively, for the 1975 samples. The application of alfalfa meal up to $1 \%$ for flooded soil (60\% moisture) resulted in a further increase in extractable $\mathrm{Mn}$, except for Convent soil.

Relative uptake of ions by plants is determined in part by the relative availability of the ions in the soil. But relative availability of $\mathrm{Mn}$ does not necessarily correspond closely with relative concentration of the extractable ion in the soil, probably because of the complicated dynamic equilibrium of $\mathrm{Mn}$ in the soil. However, these data account for a relative influence of the soil extractable $\mathrm{Mn}$ on the $\mathrm{Mn}$ content of soybean seedlings.

\section{RESUMEN}

El efecto de la adición de harina de alfalfa y del aumento en la humedad del suelo sobre el crecimiento y la concentración de manganeso en el tejido de plántulas de habichuelas soya se investigó en invernadero. La germinación disminuyó significativa- 
mente cuando el suelo se mezcló con 2 y $4 \%$ de harina de alfalfa. Aumentos en la concentración de la harina ocasionaron una disminución progresiva en el crecimiento de las plántulas, (excepto en el suelo Convent) y fue más marcado en el suelo inundado. Se sugiere que este efecto es causado por una disminución en la respiración de las semillas como consecuencia de un empobrecimiento en el suministro de oxígeno al aumentar la demanda del mismo por la flora microbiana del suelo. Otra posibilidad es que el desarrollo de substancias tóxicas en el suelo producidas por la descomposición de la materia orgánica, puedan inhibir la germinación de las semillas.

La concentración de manganeso en el tejido de las plántulas aumentó considerablemente al inundar el suelo. Las plántulas sembradas en el suelo Olivier arrojaron el más alto contenido en manganeso, las sembradas en los suelos Sharkey y Commerce acusaron uno intermedio y las sembradas en el suelo Convent el contenido más bajo.

\section{LITERATURE CITED}

1. Abdul-Wahab, A., and Rice, E. L., Plant inhibition by Johnsongrass and its possible significance in old-field successions, Bull. Terrey Bot. Club 94: 486-97, 1967.

2. Christensen, P. D., Toth, S. J., and Bear, F. E., The status of soil manganese as influenced by moisture, organic matter and pH. Soil Sci. Soc. Am. Proc. 15: 279$82,1950$.

3. Floyd, G. L., and Rice, E. L., Inhibition of higher plants by three bacterial growth inhibitors, Bull. Torrey Bot. Club 94: 125-9, 1967.

4. Fujimoto, C. K., and Sherman, G. D., Behavior of manganese in the soil and the manganese cycle. Soil Sci. 66: 131-45, 1948.

5. Gotoh, S., and Yamashita, K., Oxidation reduction potential of a paddy soil in situ with special reference to the production of ferrous iron, manganous manganese and sulfide. Soil Sci. Plant Nutr. 12: 230-8, 1966.

6. McCalla, T. M., and Haskin, F. A., Phytotoxic substances from soil microorganisms and crop residues, Bacteriol. Rev. 28: 181-207, 1964.

7. Quellette, G. J., and Dessureaux, L., Chemical composition of alfalfa as related to degree of tolerance to manganese and aluminum. Can. J. Plant Sci: 206-14, 1958.

8. Patrick, Z. A., and Koch, L. W., Inhibition of respiration, germination, and growth by substances arising during decomposition of certain plant residues in soil, Can. J. Bot. 36: 621-47, 1958.

9. Patrick, Z. A., and Toussoun, T. A., Plant residues and organic amendment in relation to biological control. In Ecology of Soilborne Plant Pathogens - Prelude to Biological Control, K. F. Baker and N. C. Snyder (ed.) p 440-59, Univ. Calif. Press, Berkeley, 1965.

10. Pearson, R. W., and Adams, F. (ed.), Soil Acidity and Liming. Agronomy No. 12, Am. Soc. Agron., Madison, Wis. 1967.

11. Ponnamperuma, F. N., The Mineral Nutrition of the Rice Plant, p. 295-328. Johns Hopkins Press, Baltimore, Maryland. 1965.

12. Sutton, C. D., and Hallsworth, E. G., Studies on the nutrition of forage legumes. 1 . The toxicity of low $\mathrm{pH}$ and high manganese supply to weerne, as affected by climatic factors and calcium supply. Plant Soil 9: 305-17, 1958.

13. Toussoun, T. A., Weinhold, A. R., Linkerman, R. G., and Patrick, Z. A., Nature of phytotoxic substances produced during plant residue decomposition in soil, Phytopathology 58: 41-5, 1967.

14. Turner, F. T., and Patrick, W. H., Jr., Chemical changes in water-logged soils as a result of oxygen depletion, Cong. Soil Sci. Trans. 9th (Adelaide, Australia), IV: $53-65,1968$. 